\title{
THE BASICS ON ACCOUNTING PROFESSION SELECTION: LATEST CAPTURE DURING COVID-19 PANDEMIC ERA
}

\author{
Nurul Azizah \\ Universitas Wijaya Kusuma Surabaya \\ Fitri Purnamasari \\ Universitas Negeri Malang \\ fitri.purnamasari.fe@um.ac.id
}

\author{
A R T I C L E I N F O \\ Article history: \\ Received: 26 February 2021 \\ Revised: 1 May 2021 \\ Accepted: 3 May 2021

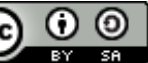 \\ Keywords: \\ COVID-19 Pandemic, Job Selection, Ac- \\ counting Students, Accounting Profession \\ DOI: \\ https://doi.org/10.33508/rima.v4i1.3048
}

\begin{abstract}
A B S T R A C T
COVID-19 pandemic era is very potential in changing the mindset of students in the accounting field in seeing their future careers. It cannot be denied that there are several factors in how they view the prospects for the accounting profession amid this pandemic. This research was conducted at a university located in Malang City, Indonesia. The data was obtained through interviews with 70 students of the Accounting Department, Faculty of Economics. Interviews were conducted in person for approximately three months in 2020. In connection with the COVID-19 pandemic, interviews were conducted online. It is revealed that financial performance rewards and an ideal work environment are the two main factors that accounting students consider in determining their career path.
\end{abstract}

\section{INTRODUCTION}

The COVID-19 virus pandemic has become a global phenomenon demanding changes in the world of education. Improving learning and teaching methods to overcome social distancing obligations is being implemented simultaneously in various countries, including Indonesia.

Through Circular Number 4 of 2020 and Circular Letter Number 15 of 2020, the Minister of Education and Culture conveyed appeals and guidelines for educational implementing institutions to carry out Learning From Home (LFH) activities. Based on the government's instructions, LFH is implemented full-time so that the teaching staff and students will fully implement distance learning as long as the pandemic is still rampant. LFH is undoubtedly done by prioritizing students' safety and inner health, educators, heads of education units, and all members of the education unit.
Most institutions have included this method in their teaching and learning activities. Offline learning is often combined with online, either synchronously or asynchronously. However, the scheme demanded by BDR in this pandemic era is full-time distance learning. These so educational institutions are accustomed to providing offline learning to prepare for changes in the teaching and learning activity system in a more in-depth way.

The existing curriculum and learning methods need to be overhauled to meet these demands. The changes that occur certainly apply to all fields of science, including accounting. The existence of this phenomenon is very potential in changing the mindset of students in the accounting field in seeing their future careers. It cannot be denied that there are several factors in how they view the prospects for the accounting profession amid this pandemic. 
These factors are revealed in Rahayu (2003) research, which states that the factors that influence it consist of financial income, professional training, professional recognition, social values, work environment, labor market considerations, and personality.

Commonly, accounting students will choose one of four careers, such as public accountants, corporate accountants, periodic accountants, or government accountants. By knowing the perceptions of accounting students regarding the factors that influence them in choosing a career, overall, every accounting student who will enter the world of work can correctly choose a career to run, especially in this pandemic era. It does not rule out; if accounting students have graduated, they will be better prepared to enter the world of work and more accessible to adjust their abilities.

\section{LITERATURE REVIEW}

\section{Accounting Profession in Indonesia}

According to the International Federation of Accountants, what is meant by the accounting profession is all fields of work that use expertise in the accounting field, including the work of public accountants. These internal accountants work for industrial, financial, or trade companies, accountants who work in agencies: government, and accountants as educators.

Accounting practice in Indonesia began in the VOC era (1642). Minister of Education Decree No. 179/ U/ 2001 states that accounting profession education is additional education in higher education after the undergraduate economics program in the accounting study program. Accounting professional education aims to produce graduates who master the expertise of the accounting profession and provide professional accounting compensation.

Accounting profession education graduates are entitled to hold the title of the accounting profession (Benny, 2006), then they must register with the finance department to get a registration number. Especially for teaching accountants, to pursue this profession, a Bachelor of Accounting degree must take further education, namely Strata 2 or S2 education; after completing this education, graduates can work as teachers at schools or lecturers at State or Private Universities.

The development of the accounting profession in Indonesia has been relatively rapid, along with developing the business world in Indonesia; many public accounting firms (KAP) have emerged in Indonesia, both local and foreign-owned. According to Law No.5/ 2011 Article 1, paragraph 5 states a public accounting firm, after this abbreviated as KAP, is a business entity established based on the provisions of laws and regulations and obtains a business license the Law.

According to Naukoko (2017), currently, the state of accountants in Indonesia has reached its newest stage, has become a founding member of the ASEAN Economic Community (AEC) since December 2015. It should be noted that there are many impacts from the entry of AEC in Indonesia, starting from the formation of free trade to the impact of various professions in Indonesia, including accountants.

For accountants, AEC provides many opportunities, as well as challenges. Several opportunities and challenges arose from the existence of the Mutual Recognition Agreement (MRA). MRA is an acknowledgment made jointly by ASEAN member countries regarding professional and professional services that are licensed or certified. Of the many existing professional services, accounting services are one of them. The enactment of the MEA and the existence of the MRA should be able to trigger the preparation of accountants and prospective accountants in facing the MEA. In her blog, Martani (2021), an expert and professional practitioner in the field of accounting in Indonesia, mentions several headline statements that need to be paid attention to by all students, educators, and accounting practitioners in Indonesia:

"The AEC (ASEAN Economic Community) has started, the market for goods and services of ASEAN countries will move 
seamlessly be-tween countries. Countries that have a competitive advantage will win the competition and vice versa. Accountant services are one of the services that have been opened in the MEA agreement. Accounting education must be developed with international standards to answer the challenges of the AEC. Free flow also occurs for the professional workforce. Workers will find it easy to work in ASEAN countries without obstacles. Not all professionals are opened in the ASEAN free market. currently just started for engineering services, architects, nursing services, medical practitioners, dental practitioners, accounting and survey services."

Several sentences of the statements above by Martani (2021) at the same time become a warning for accounting educators to prepare their graduates better to face the reality of the consequences of AEC. In addition, at an event held by Gadjah Mada University (UGM) and the Indonesian Accountants Association, Prof. Dr. Ainun Na'im, MBA- Secretary-General of the Ministry of Education and Culture of the Republic of Indonesia, also urged that educational institutions need to change the curriculum so that students. It can help the students to catch better opportunities or learning processes.

This policy is related to the current world situation, which is also in the COVID19 pandemic. This policy is very urgent to be carried out in such a way so that learning continues to be effective. Then, even though conducive learning has been maintained, we must maintain that the accounting education we provide to society remains relevant to the needs of society. Because, in some cases, the COVID pandemic like AEC has also accelerated the process of change (Budiarso \& Chanifah, 2020).

At the same event, Dr. Singgih Wijayana, one of the educators in accounting in Indonesia, also gave some of his responses to found new facts from several literature studies. This fact is that the needs of graduates are no longer relevant to the long-term needs of these graduates.

"Most of the current curriculum focuses on preparing graduates who have entry-level requirements that were relevant in the past, and not now. It is important to prepare graduates' long-term career needs ... It would be less appropriate if the current changes only focus on accounting competencies. A person with an accounting background must have other competencies that support his or her competence, to support their profession." (Budiarso \& Chanifah, 2020).

Dr. Singgih also added that there needs to be a broader addition of skills and competencies of accounting graduates because currently, the contemporary business and organizational environment is in dire need of it. Although currently, accounting education is mostly still focused on preparing careers for public accounting or auditing. Several studies conducted by Suryani et al. (2018) and Sawarjuwono \& Kalanjati (2013) have found that many accounting study program graduates are produced each year. However, only a few choose careers as public accountants.

This phenomenon can also be predicted, considering that accounting graduates can also pursue various careers apart from becoming accountants. Quoted on the Sun Education Group website (2020), accounting graduates can also choose to become employees of government financial institutions, to become entrepreneurs, and have careers independently.

The Indonesian government has various financial institutions such as Bank Indonesia (BI) and the Financial Services Authority (OJK), which generally recruit accounting graduates. However, the competition may be very tight. A job in a government company might be a source of pride as a financial one because the salaries offered to staff at the two institutions above will be far above the average for other accountants.

Then, accounting alumni who want to build a business independently can also pursue careers as entrepreneurs. This situation is possible, considering they have financial knowledge, and it will make them more thorough, observant, and calculate business opportunities. However, not all accounting 
graduates can undoubtedly have a proper entrepreneur mindset.

Therefore, it is essential for accounting students to think about career choices so that when they graduate, there will be various views on what job level they will choose.

\section{Choosing A Profession: Expectancy Theory and Maslow's Hierarchy of Needs}

Expectancy Theory tends to act differently depending on the strength or expectation that the action will be followed by a specific thing for each individual (Robbins, 2011). Expectations will affect a person's attitude, according to Robbins (2011).

A person's attitude is formed from three components: cognitive components, emotional components, and behavior components.

1. A cognitive component is a belief in the information that a person has that will influence one's attitude towards the profession to be undertaken.

2. The emotional component is an emotional feeling that someone has to like something. When someone likes something, a person will tend to try to get it.

3. The behavior component is an activity to act more specifically in responding to events and information from outside so that a person will be motivated to run a high level of business if he believes that the effort will lead him to better performance.

Abasara (2011) states that the key to expectation is understanding individual goals and the relationship between effort and performance, between performance and rewards. Therefore, accounting students' career choice is determined by the career expectations when they pursue that career, whether this career can meet the needs they want and provide unique appeal to these individuals.

The expectations that arise in a person trigger someone's motivation to reach the expectations they want to get. Likewise, in choosing a profession, in choosing the desired profession, there is an expectation of the desired profession, and to achieve it requires motivation as support. Maslow (1943) in Robbins (2011) based the concept of a hierarchy of needs on two principles.

First, human needs can be arranged in a hierarchy from lowest to highest needs. The second is that a need that has been satisfied ceases to be the primary motivator of behavior. According to Maslow, humans will be encouraged to fulfill the most substantial needs according to the time, circumstances, and experiences concerned following a hierarchy.

This theory states that even though no need is ever completely met, a substantially satisfied need no longer motivates a person. According to Oktavia (2006), humans must work or have a career to get a salary or other compensation to meet these needs to fulfill physiology. Besides that, it also requires a sense of security, appreciation, and self-actualization while he is working.

\section{RESEARCH METHOD}

This type of research used in this research is qualitative research with an interpretive approach. This approach is considered suitable for research that wants to understand social or cultural events based on the experiences of actors/informants in constructing meaning.

An interpretive approach departs from an attempt to explain social or cultural events based on the perspectives and experiences of the people studied. In general, the interpretive approach is a social system that interprets behavior in detail, directly observing. In addition, case studies are used as a research strategy as this is intended to give researchers flexibility in collecting deeper data. In this study, the researcher himself acts as a human instrument.

The research was conducted at a university in Malang City, Indonesia. The research data was obtained through interviews with 70 students of the Accounting Department, Faculty of Economics. Interviews were conducted in person for approximately three 
months in 2020. In connection with the COVID-19 pandemic, interviews were conducted online.

The data collection method in this research is using an in-depth interview method. Previously, the researcher made a frame of interview questions as a reference for extracting data from informants. However, the interviews will be semi-structured, so the number of questions asked will grow, following the answers given by the informants. An outline of the interview questions is attached at the end of this report. The type of data obtained is primary data. Primary data were obtained from transcripts from interviews by researchers to informants.

Data were analyzed using the Miles \& Huberman model (Sugiyono, 2010), consisting of data reduction, data presentation, and data verification. Data analysis was carried out through data thematization. The validity of the findings obtained during the research process will be tested by increasing persistence.

\section{RESULTS AND DISCUSSIONS}

Several interviews were conducted with several student informants at certain times during the COVID-19 pandemic. Interviews were conducted for several subtopics of concern regarding career choices in accounting. Then, some questions were also asked in a semi-structured manner to add to the richness of the research data.

Some of the subtopics concern Financial rewards and the Work Environment. Especially for Financial Rewards, the in-formers also provided many views on Nominal and Increase in Basic Salary and Providing Pension Fund Schemes to Workers. This data acquisition certainly creates a phenomenon that the focus of the prospective accounting study program graduates who are the object of this research turns out to have a more view of these two things. The following is an explanation of some of the informants' views.

\section{Financial Rewards}

\section{Nominal and Increase in Basic Salary}

Financial rewards or salaries obtained from work are fundamentally the main attraction for giving satisfaction to employees. Currently, financial rewards are one measure used in measuring performance satisfaction and consideration in career choices.

Several previous studies regarding the factors influence career choices stated that financial rewards are one of the factors driving students in career choices (Oktavia, 2006). The same thing is also expressed by Wijayanti (2001), stating that financial rewards are the results obtained as performance contracts which some companies believe as the main attraction for making decisions to employees. not only that, financial rewards / salaries are a factor that students consider in choosing a profession.

Through data collection that has been carried out, students as research respondents agree that nominal and basic salary increases are important in choosing their career path. The total collected as much as $91.55 \%$ of respondents who expressed this.

One respondent revealed that salary is essential for career considerations. Later, the cost of living will be more expensive, and the needs will increase so that it requires much money. Moreover, with a salary, we can invest and save money when we retire. Other respondents agreed on this statement:

"Because in terms of gender, I am a man, in the future, I will have dependents, both wife and children. I think it is quite rational if I look at the nominal salary in my career."

Other respondents said that apart from supporting their needs, salaries can also be used to develop their potential. In other words, a salary increase will also affect employee productivity because the company must give every employee or worker appreciation for the performance that the employee has done so that the employee feels appreciated and feels excited about a career. A similar opinion was also expressed by most of the 
respondents. This is also expressed in the following opinion:

"I think the basic salary is one of the important things to look at when looking for a job because in my opinion salary is one of the results of my appreciation for my performance. With the salary increase, it is also possible to deny that we will be enthusiastic at work."

"Because the nominal amount and increase in basic salary that will be received will also have a good impact on workers to optimize their performance more, and have a passion for work to give their best."

This opinion certainly makes the salary and the increase as motivation in determining the career of students as respondents in this study. The same thing was also expressed by other respondents, as follows:

"This is important because a salary increase is a sign that our performance in the company is appreciated, especially if the company has experienced a significant increase in profit or turnover for several years. Salary increases are important to appreciate and appreciate the performance of company employees. This condition also improve the company image, where employees are respected and shared in the welfare of the company."

On the other hand, some students argued that the basic salary and its increase was reasonable to seek and prioritize. The nominal value and increase are quite important in career choices because it cannot be denied that the purpose of working is to earn income, and this income is obtained from a lawful job.

"The most important thing is (the salary) is halal."

"A salary increase is indeed important, but my priority is comfort at work. it is useless a high salary but no comfort at work."

Tt should also be noted that according to Bachtiar (2002), the public accounting profession is one of the 33 most expensive professions because the largest source of income from public accountants has shifted from audit services to management consulting services. Abasara (2011), in his research about career as a public accountant, states that the financial reward/ salary variable has a significant effect on career choices as a public accountant. in another study, Yendrawati (2007) stated that students choose careers as public accountants and corporate accountants consider that with that career, they will get a high starting salary. Andersen (2012) added in his research, in general, accounting students have the view that accountants have a good salary.

What was revealed in the studies actually in line with the statements of the research respondents (accounting students). They are classified as concerned about income from the work to be chosen later.

\section{Providing Pension Fund Schemes to Work- ers}

The employer pension fund (in Indonesia, it is called the Dana Pensiun Pemberi Kerja or DPPK) is a pension fund established by an employer for part or all of its employees. Employers who set up pension funds are called founders. dppk membership is limited to part or all of the founding employees. However, pension fund membership may also be open to employer employees who participate in the pension fund. Employers who enroll their employees in pension funds set up by other employers are called founding partners.

Rahayu (2003), in their research, revealed that financial rewards can be measured in several ways, such as (1) the amount of the initial salary. (2) pension funds, and (3) quick raise. basically, as a means of supporting financial rewards, pension funds have a longterm nature. Some of the contributions collected from participants at this time will only be withdrawn when the participants have retired so that the pension fund program can provide income development to its participants.

The pension fund has an added value compared to other financial institutions with 
its function, namely to provide security and security to employees as participants of the pension program. Therefore, it is only natural for these participants to know the financial performance to ensure the ability of the pension fund to pay pension benefits in the future (nussy, 2014).

When asked about how important the provision of pension funds is to workers, the research respondents then gave their views according to their perspectives. One respondent even cited the positive and negative sides of the provision of funds, as follows:

"In my opinion, there are two sides to this, namely negative and positive. The positive is that in the old days, you don't need to be confused about finding money again or becoming a burden for the child. The negative side is that because of the obvious convenience; some people do not give the ability they have maximally. "

Some respondents also said that the current pension fund scheme is considered better for them if they have worked later. The new fully funded model implemented by the government for civil servants is classified as more effective and efficient for them. As is well known, the pension fund scheme with such a system will be directly received by retired workers with a large total nominal, different from the previous scheme. However, there is a special view of one respondent who has the same opinion, as quoted below:

"I agree with the current scheme, but for civil servants (candidates), the recruitment (can) be more effective and efficient because many civil servants eat blind salaries."

However, the majority of respondents agreed that providing a pension fund scheme was the right step to help maintain the welfare of the workforce. The pension fund is considered to be something that is taken into account when determining whether a financial reward is good in a company or a certain career path in order to maintain the commitment of the workforce to the agency that employs it. This was revealed in the respondent's opinion as follows:
"In my opinion, an office worker is paid when they work and when they are old, they are not able to work, pension funds will be very meaningful. Companies are obliged to provide pension funds for their employees so that employees will also give their best dedication to work. The company. "

"It is very good, seeing the pension fund become a savings for workers when they have retired from their workplace so that they have money reserves when they are not working"

From one of the opinions above, it can be seen that the pension fund scheme given to workers who have undergone retirement is a good thing that can be used as a cost reserve for the worker's family if viewed from the perspective of the respondents of this study.

Suppose the financial award for dedication is given while working in the form of a salary and continued with the pension funds at retirement. In that case, it is possible that the respondents chose to take into account the pension fund as a determinant of their choice of career paths. This is also in line with what the following respondents said:

"I totally agree with the pension fund. They had devoted themselves to work when they were young. So that when you are old, you must be respected, not with a trivial pension fund. It must be with the appropriate funds so that it doesn't harm the pensioner. "

\section{Work Environment}

The work environment is very supportive in choosing a career because a safe and pleasant work environment can improve employee performance. The work environment generally also relates to the type of work and the work environment. Andersen (2012) states that the work environment is a work atmosphere includes the nature of work (routine, attractiveness, and intensity of overtime hours), the level of competition among employees, and work pressure are factors of the work environment.

A tough character and commitment are needed by an accountant in facing the work 
environment; a worker is required to be able to adapt and socialize with the work environment in order to achieve the required work targets. The results and discussion of work environment factors will be presented in the following section.

Merdekawati and sulistyawati (2011) revealed that the work environment describes several things such as routine work, whether or not the work can be completed, challenges at work, pleasant work environment, frequent or not overtime work, the level of competition between high employees, until there is work pressure to achieve perfect results. All of which can certainly be a measure of an ideal work routine.

Most of the research respondents, through the interview process, admitted that they worked eight hours a day, starting from the morning to the evening, for five days a week. According to them, this time is the optimal time for them to work and work productively. In addition, the majority of respondents also added that the ideal work routine, in their opinion, is at least not too many overtime hours for them to work. However, if there are forced overtime hours, there should be additional wages or bonuses following the scope of work that is being carried out.

Some respondents emphasized the ideal definition with various other aspects, such as the existence of a work environment that can support the balance between professional life and personal life. They consider the existence of such a situation as an effort to support the effectiveness and efficiency of the use of daily work time. This is reflected in the opinions of the following respondents:

"... The working hours and payroll system are clear, the division of tasks and the determination of targets is clear. There is no seniority in providing training to barmen; there is an atmosphere of solidarity at work, does not involve personal matters in every decision making."

"In my opinion, the ideal work routine is work that has the same duration of time throughout the day does not interfere with our time for other activities. "

"Does not interfere with the 5 times prayer."

On the other hand, referring to previous research by andersen (2012) as well as merdekawati and sulistyawati (2011), that work pressure which is full of challenges and competition is what needs to be considered in assessing the work environment, respondents agreed to share their views as follows:

"Pressure and competition in the work environment is interesting because it encourages someone to work better and be superior. As long as the competition is done without cheating, it is good."

"Very good because it will spur every individual in the company to be better."

"A work environment that is full of challenges and competition is very good for employee development, provided that the competition is healthy competition."

The respondents considered the presence of a competitive and challenging atmosphere because it could help them to improve their skills again and be able to compete with other workers. According to them, the existence of a work environment that is full of challenges will improve and train the abilities of workers in any case. So that later when they are faced with more difficult situations, they will automatically be better trained and can get through it well.

Interestingly, some respondents said that a competitive atmosphere, in particular, can be a medium for socializing and must be in life to train them mentally. The following are quotes from these opinions.

"I think this is natural because the challenges and competitions sometimes allow me to be close to other people (as long as this competition is fair)."

"In my opinion, competition must exist in life because when there is no competition, it causes people to stagnate and do not want to change for the better. Humans can easily be jealous of the success of others, envy here in a positive sense. So that they are motivated to be better than him. " 
The existence of challenges and competitions in life is considered something natural in the world. Another important thing is that these conditions can be a motivation for someone to compete and indirectly experience changes in changes in his life. The condition of the competition that can motivate is related to the motivational climate.

Sulistiobudi \& Kadiyono (2017) state that the concept of motivational climate that has developed since the 1980s and is more dominant in discussing achievement in the context of education and sports (Carole Ames \& Ames, 1984; Nicholls, 1984), shows that motivational climate significantly influences employee work engagement. Conducted on 76 employees in one of the soes (stated owned enterprises) in west java, the research involved motivational climate factor in the context of work with the approach of industrial and organizational psychology and its relationship to employee's work engagement.

Specifically, the research puts motivational climate as a resource in the framework of job demand resource model, which helps employees in facing job challenges so that they feel more engaged in their work. Sulistiobudi \& Kadiyono (2017) also mentioned that apart from the motivational climate in educational psychology; there is one other factor that dominates the most, namely the mastery climate. It can enhance adaptive learning and motivation. This hypothesis is supported by various studies (Patrick, Kaplan, \& Ryan, 2011).

Apart from the various factors that have an influence in motivating someone to do certain jobs, various support systems are needed within the company for self-development and many programs to improve employee abilities. Like the previous informant's opinion, there is a positive and fair climate that encourages competition among employees to be implemented in conjunction with these opportunities for self-development

\section{CONCLUSION}

In order to face the demands of work and challenges that are getting tougher in the future, readiness regarding professional professionalism is necessary. In this study, the factors that influence the career choice of accounting students have been revealed.

Several interviews were conducted with students who acted as respondents in this study. It is revealed that financial performance rewards and an ideal work environment are the two main factors that accounting students consider in determining their career path.

In more detail, the students said that nominal and basic salary increases and the provision of pension fund schemes for workers need to be considered in discussing financial rewards in a scope of work. In addition, the existence of a competitive and ideal atmosphere in the work environment is also considered necessary in the careers of accounting students in order to stimulate their productivity, effectiveness, and work efficiency.

\section{REFERENCES}

Absara, L., (2011), Faktor-faktor Yang Mempengaruhi Mahasiswa Akuntansi Dalam Pemilihan Karir Menjadi Akuntan Publik. Undergraduate Thesis. Fakultas Ekonomi Universitas Diponegoro.

Andersen, W., (2012), Analisis Persepsi Mahasiswa Akuntansi dalam Memilih Profesi sebagai Akuntan. Undergraduate Thesis. Fakultas Ekonomi Universitas Wijaya Kusuma Surabaya

Apriliyan, L. A., (2011), Faktor-Faktor yang Mempengaruhi Mahasiswa Akuntansi Dalam Memilih Karir Menjadi Akuntan Publik. Undergraduate Thesis. Fakultas Ekonomi Universitas Diponegoro.

Bachtiar, A. M., Iskandar, (2002)., Akuntansi Pemerintahan, Salemba Empat

Budiarso, S., \& Chanifah, L. Z. (2020). Tantangan Pendidikan Akuntansi dan Profesi Akuntan dalam Era 
Kenormalan

Baru.

https://feb.ugm.ac.id/id/

berita/3079- tantangan-pendidikanakuntansi-dan-profesi-akuntan-dalamera-kenormalan-baru

IFAC (International Federation of Accountants \& IASB (International Accounting Standards Board)

Keputusan Menteri Pendidikan Nasional Republik Indonesia Nomor 179/U/2001 tentang Penyelenggaraan Pendidikan Profesi Akuntansi

Martani, D. (2021). Profesi Akuntan dalam Menghadapi MEA. https://staff.blog.ui.ac.id/martani/about/pe mikiran-yangdisajikan-dalam-koranmajalahpopulerumum/profesi-akuntan-dalam-menghadapi-mea-2/

Maslow, A. H. (2013). A Theory of Human Motivation. Simon and Schuster.

Mas'ud Fuad (2004), Badan Penerbit Universitas Diponegoro Semarang. Jurnal Akuntansi dan Auditing Indonesia 9(2)

Merdekawati, D. P., \& Sulistyawati, A. I. (2011). Faktor-faktor yang Mempengaruhi Pemilihan Karir Akuntan Publik dan Non Akuntan Publik. Jurnal Ilmiah Aset, 13(1), 9-19.

Naukoko, P. A. (2017). Profesi Akuntan Di Era Masyarakat Ekonomi Asean (Mea). Journal of ASEAN Studies on Maritime IIsues, 3(4), 1-50.

Nussy, A. F. (2014). Analisis Penerapan PSAK N0. 18 Mengenai Akuntansi Dana Pensiun pada PT. Taspen Cabang Manado. Jurnal EMBA: Jurnal Riset Ekonomi, Manajemen, Bisnis dan Akuntansi, 2(4).

Oktavia, (2006), Pengaruh Kompetensi, Independensi, Profesionalisme, Pengalaman Kerja dan Komitmen Organisasi terhadap Kualitas Audit
Rahayu, S., (2003), Persepsi Mahasiswa Akuntansi Mengenai Faktor-Faktor Yang Mempengaruhi Pemilihan Karir, Simposium Nasional Akuntansi VI

Robbins, S.P., (1996). Perilaku Organisasi, Konsep, Kontroversi dan Aplikasi. Alih Bahasa: Hadyana Pujaatmaka. Edisi Keenam. Jakarta: PT. Bhuana Ilmu Populer.

Sawarjuwono, T., \& Kalanjati, D. (2013). Menumbuhkan Cinta Profesi Akuntan Publik bagi Generasi Penerus. Jurnal Akuntansi Dan Bisnis, 13(1). https://doi.org/http://dx.doi.org/10. 20961/ jab.v13i1.132

Sugiyono. (2010). Metode penelitian kuantitatif dan R\&D. Alfabeta.

Sulistiobudi, R. A., \& Kadiyono, A. L. (2017). Menumbuhkan Keterlibatan Positif dalam Bekerja: Melalui Iklim Kompetisi ataukah Pengembangan Kompetensi? Psikohumaniora: Jurnal Penelitian $\begin{array}{lll}\text { Psikologi, } & 2(1),\end{array}$ https://doi.org/10.21580/pjpp.v2i1.12 73

Suryani, A. W., Helliar, C., Carter, A. J., \& Medlin, J. (2018). Shunning Careers in Public Accounting Firms: The case of Indonesia. British Accounting Review, 50(5), 463-480.

Undang-Undang Republik Indonesia Nomor 5 Tahun 2011 tentang Akuntan Publik Pasal 1-Pasal 6

Wijayanti, (2003), Faktor-Faktor yang Mempengaruhi Pemilihan Karir Mahasiswa Jurusan Akuntansi di Yogyakarta, Jurnal Riset Akuntansi Indonesia, Vol. 3, No.2.

Yendrawati, R. (2007). Persepsi Mahasiswa dan Mahasiswi Akuntansi Mengenai Faktor-faktor yang Mempengaruhi Pemilihan Karir sebagai Akuntan. Jurnal Fenomena, 5(2), 1-11 